\title{
Distribution and Abundance of Unexploited Fish Species in Three Sri Lankan Reservoirs
}

\section{P.A.D. AJITH KUMARA ${ }^{1}$, U.S. AMARASINGHE ${ }^{2 *}$, F. SCHIEMER ${ }^{3}$, G. WINKLER ${ }^{4}$ and M. SCHABUSS ${ }^{3}$}

\author{
${ }^{1}$ National Aquatic Resources Research \& Development Agency \\ Crow Island, Colombo 15, Sri Lanka \\ ${ }^{2}$ Department of Zoology, University of Kelaniya \\ Kelaniya 11600 Sri Lanka \\ ${ }^{3}$ Department of Limnology and Hydrobotany, Faculty of Life Sciences \\ University of Vienna, A-1090 Vienna, Althanstrasse 14, Austria \\ ${ }^{4}$ Austrian Academy of Sciences, Institute for Limnology \\ A-5310 Mondsee, Gaisberg 116, Austria
}

\begin{abstract}
In the reservoirs of Sri Lanka, two exotic cichlid species, Oreochromis mossambicus and $O$. niloticus are dominant. Small indigenous cyprinid species are abundant in reservoir fish communities, but they remain unexploited due to poor consumer preference. In the present paper, an attempt is made to investigate the spatial and temporal fluctuations of distribution of these unexploited small indigenous cyprinid species in three reservoirs of Sri Lanka. Experimental fishing with multi-mesh gillnets $(12.5 \mathrm{~mm}$ to 37 $\mathrm{mm}$ stretched mesh) having the spread height of $1.5 \mathrm{~m}$, was carried out in inshore and offshore areas of the three reservoirs during the seasons of high and low water levels. As cichlids exhibit depth preference with size, their juveniles were not caught in these gillnets which were set in offshore areas with depths greater than $1.5 \mathrm{~m}$. Amblypharyngodon melettinus, Puntius chola and $P$. filamentosus were found to be the most abundant species in all three reservoirs. The species composition in the gillnet catches appears to be influenced by water level fluctuations in reservoirs perhaps due to inshore-offshore migration of individual fish species associated with water level fluctuations. Despite the site-specific differences in species distribution and abundance and their temporal variations, a small mesh $(12.5 \mathrm{~mm}$ to $37 \mathrm{~mm})$ gillnet fishery with the minimum panel height of $1.5 \mathrm{~m}$ can be introduced to exploit small indigenous cyprinids in Sri Lankan reservoirs without harming the existing fishery of exotic cichlids.
\end{abstract}

\footnotetext{
Corresponding author. Tel.: +94 112903 397, Fax. +94 112914479

E-mail address: zoousa@kln.ac.lk
} 


\section{Introduction}

The reservoir fishery of Sri Lanka, albeit based almost entirely on two exotic cichlid species, Oreochromis mossambicus and O. niloticus (De Silva 1988; Amarasinghe 1998), is highly productive compared to the average annual yield of about $80 \mathrm{~kg} \cdot \mathrm{ha}^{-1}$ in tropical lowland reservoirs (Oglesby 1985). However, about 38 species are known to represent reservoir fish fauna of Sri Lanka (Fernando 1984; Pethiyagoda 1991). Most of these indigenous fish species are not exploited in Sri Lankan reservoirs. Fernando and Holčik (1991) have suggested that due to the inability of indigenous fish species of riverine origin to sustain productive fisheries in tropical reservoirs, introduction of lacustrine or lacustrine-adapted fish species is necessary to establish productive fisheries. However, Schiemer and Hofer (1983) have found that there are sizeable populations of smallsized indigenous cyprinids in a Sri Lankan reservoir. Based on these findings, Amarasinghe (1985), De Silva and Sirisena (1987) and Pet and Piet (1993) have carried out detailed surveys and found that small-sized cyprinid species such as Amblypharyngodon melettinus, Puntius chola, P. dorsalis and $P$. filamentosus named as minor cyprinids to differentiate from Gangetic and Chinese major carps, are abundant in Sri Lankan reservoirs. They have also shown that these species can be differentially harvested using small-mesh (<52 mm stretched mesh size) gillnets without harming the existing reservoir fishery based on exotic cichlids. Due to the high turnover rates of these small-sized cyprinids, they are capable of sustaining fisheries (Amarasinghe et al. 2002).

It has been shown that there is a high potential for establishing a subsidiary gillnet fishery for minor cyprinids in Sri Lankan reservoirs for more complete utilization of the fish resources (De Silva and Sirisena 1989; Amarasinghe 1990; Pet et al. 1996). However, as shown by Amarasinghe $(1985 ; 1990)$, activity patterns of various minor cyprinid species vary during different time intervals of the day and their catchabilities in gillnets are influenced by water level fluctuations in the reservoir. Although present in high densities, minor cyprinids are not conventionally exploited in Sri Lankan reservoirs due to poor consumer acceptability (Piet and Vijverberg 1998; Amarasinghe et al. 2002). Amarasinghe (1990) indicated that these minor cyprinids are a source of potential supplementary income for fishers in Sri Lankan reservoirs. Also, as shown by Amarasinghe et al. (2002), they can be used to produce fishmeal to feed fish fingerlings reared in net cages and ponds for the development of culture- 
based fisheries in village reservoirs. Some evidence is found in other south Asian countries such as Bangladesh that small indigenous fish species have significantly high potential for contributing to human nutrition, especially due to the reason that some species such as Amblypharyngodon mola are found to be rich in vitamin A (Roos et al. 2007). In order to exploit minor cyprinids in reservoirs without harming the existing fishery based on cichlids, it is imperative that a two-tier fishery which can co-exist be established in which cichlids are exploited by larger mesh $(>8.5 \mathrm{~cm}$ stretched mesh sizes) gillnets while minor cyprinids are exploited by gillnets of 1.5 to $5.2 \mathrm{~cm}$ stretched mesh sizes. Hence, knowledge about the abundance and distribution of minor cyprinids is important for the purpose.

Minor cyprinids are somewhat comparable to small pelagic fish species in marine environments due to the reason that they move freely in the water-column (pelagic domain) where they spend most of their time. As many small pelagic fishes in marine habitats, minor cyprinids such as A. melettinus in Sri Lankan reservoirs exhibit gregarious spatial behaviour (Schiemer and Hofer 1983). Hofer et al. (2003) have shown that a unique gill structure consisting of a double row of fine appendices bordering the gill lamellae is present in A. melettinus and that the changing position of appendices correlates with diurnal feeding during day-time and swimming during night. Based on this evidence, it was hypothesized that minor cyprinids exhibit distribution patterns which may vary in time and space and according to the species. Such spatial and temporal variations in distribution patterns of fish species are needed to be investigated to identify the general pattern shared by different species in the same habitat and even by the same species in different habitats, which might have a potential use for planning management strategies for a new fishery for minor cyprinids. In the present paper an attempt is made to investigate the spatial and temporal fluctuations of distribution of unexploited small indigenous fish species in three reservoirs of Sri Lanka.

\section{Materials and Methods}

\section{Study area}

The present study was carried out in three reservoirs of Sri Lanka

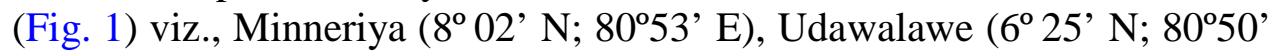
E) and Victoria ( $\left.7^{\circ} 13^{\prime} \mathrm{N} ; 80^{\circ} 47^{\prime} \mathrm{E}\right)$. Minneriya and Udawalawe are irriga- 


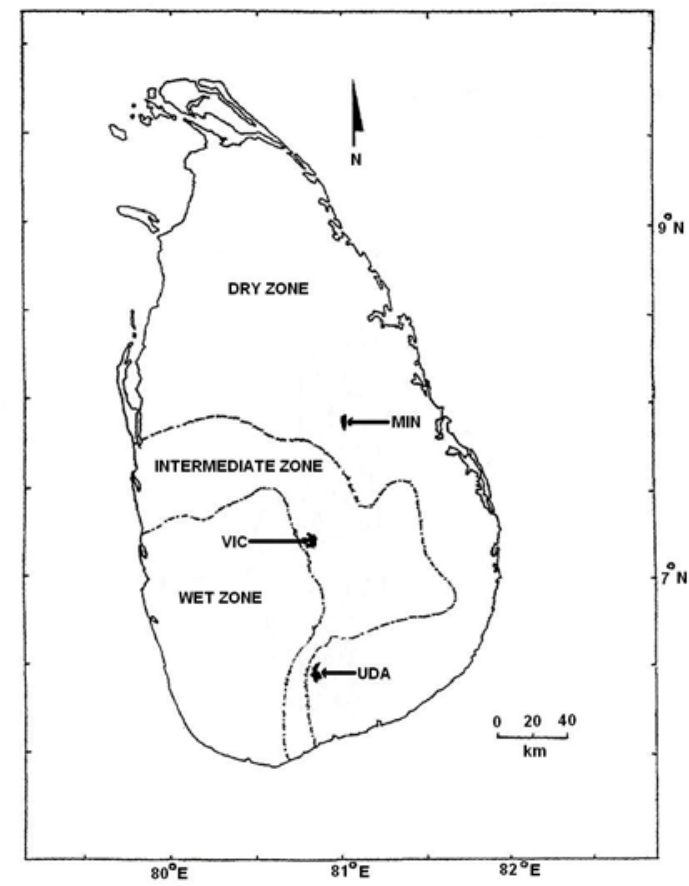

Figure 1. Map of Sri Lanka showing locations of the three reservoirs studied. MIN - Minneriya; UDA - Udawalawe; VIC - Victoria (modified after Silva and Gamlath 2000). tion reservoirs and Victoria is a hydroelectric reservoir. As a result of the release of water for irrigation and hydroelectricity generation, all three reservoirs are subjected to heavy drawdown in spite of the pulses of inflow from associated rivers during the rainy seasons. Some morphometric, hydrological and physico-chemical parameters are presented in table 1 . These reservoirs support profitable fisheries and exotic cichlid species, O. mossambicus and O. niloticus form over $80 \%$ of the landings (Sricharoendham et al. 2008). Minor cyprinids in all three reservoirs remain virtually unexploited although some fishers in Minneriya reservoir exploit them sporadically (Amarasinghe 1990).

\section{Experimental fishing}

Fishes were sampled approximately bi-monthly between January 1999 and January 2001 but sampling dates and intervals were not identical in the three reservoirs. On each sampling date, fishes were sampled from morning until late dusk using multi-mesh, mono-filament gillnets (12.5, 16, 20, 25, 33, $37 \mathrm{~mm}$ stretched mesh size). The panel height of gillnets used was 1.5 - $2.1 \mathrm{~m}$. The length of net panel ranged from $10.7 \mathrm{~m}$ for 12.5 $\mathrm{mm}$ mesh gillnet to $18.7 \mathrm{~m}$ for $37 \mathrm{~mm}$ mesh gillnet. Gillnet fishing was carried out in the shallow, inshore areas (at about $1.5 \mathrm{~m}$ water depth) and offshore areas (deeper than $1.5 \mathrm{~m}$ ) separately. Gillnets were exposed for about 30 minutes. In each gillnet fishing trial, numbers and weights of fish caught per gillnet were recorded for each species separately.

\section{Water level data}

Data on mean monthly water levels of Minneriya reservoir were obtained from the Irrigation Department and those of Udawalawe and 
Victoria reservoirs were obtained from the Mahaweli Authority of Sri Lanka. In each reservoir, mean water level for the entire period was estimated and the months with water levels above and below the overall mean were noted. The months with water levels above the overall mean were considered as months of high water level and those with water levels below the overall mean were considered as months of low water level.

Table 1. Some morphometric, hydrological, physico-chemical and biological parameters of the three reservoirs studies. Source: Weliange and Amarasinghe (2007) and Silva et al. (2008).

\begin{tabular}{lccc}
\hline \multicolumn{1}{c}{ Parameter } & Minneriya & Udawalawe & Victoria \\
\hline Type & irrigation & irrigation & hydropower \\
River basin & Mahaweli & Walawe & Mahaweli \\
Years of construction & $\begin{array}{c}\text { 276 AD } \\
\text { (Renovated in }\end{array}$ & 1969 & 1988 \\
& $1903)$ & & \\
Altitude (m above mean sea & 96 & 88.4 & 438 \\
level) & & & \\
Area $\left(\mathrm{km}^{2}\right)$ & 25.5 & 34.1 & 22.7 \\
Mean depth $(\mathrm{m})$ & 5.8 & 7.9 & 30.5 \\
Maximum depth $(\mathrm{m})$ & 13.0 & 20 & 98.0 \\
Volume $\left(\mathrm{x} 10^{6} \mathrm{~m}^{3}\right)$ & 170.2 & 268 & 783 \\
Catchment area $\left(\mathrm{km}^{2}\right)$ & 249 & 1,164 & 1,891 \\
Dead storage $\left(\mathrm{x} 10^{6} \mathrm{~m}^{3}\right)$ & 3.2 & 26.26 & 34 \\
Shoreline $(\mathrm{km})$ & 60.4 & 53.0 & 261.0 \\
Shoreline development & 2.78 & 4.38 & 7.92 \\
Temperature $\left({ }^{\circ} \mathrm{C}\right)$ & $26.5-31.5$ & $26.5-29.2$ & $20.0-24.6$ \\
Conductivity $\left(\mu \mathrm{S} \cdot \mathrm{cm}^{-1}\right)$ & $97-203$ & $102-160$ & $65-80$ \\
Secchi depth $(\mathrm{cm})$ & $45-280$ & $50-250$ & $170-260$ \\
Chl-a $\left(\mu \mathrm{r} \cdot \mathrm{l}^{-1}\right)$ & $6.0-40.0$ & $5.0-14.0$ & $6.8-22.0$ \\
\hline
\end{tabular}

\section{Data analysis}

Catch per unit effort (CPUE) values, expressed as numbers (CPUE in numbers) and weight (CPUE in weight) per $100 \mathrm{~m}^{2}$ of net per hour, were estimated for each species caught in the gillnets.

As a measure of relative abundance and commonness of each species in gillnets, an index of relative importance (IRI; Kolding and Skaalevik 2007) was used: 


$$
\text { IRI }_{j}=\frac{\left(\% \mathrm{CPUE}_{\mathrm{w}_{j}}+\% \mathrm{CPUE}_{\mathrm{N}_{\mathrm{j}}}\right) \mathrm{F}_{\mathrm{j}}}{\sum_{\mathrm{j}=1}^{\mathrm{m}}\left[\left(\% \mathrm{CPUE}_{\mathrm{w}_{j}}+\% \mathrm{CPUE}_{\mathrm{N}_{j}}\right) F_{\mathrm{j}}\right]} \times 100
$$

where $\% \mathrm{CPUE}_{\mathrm{Wj}}$ and $\% \mathrm{CPUE}_{\mathrm{Nj}}$ are percentage CPUE in weight and in number, respectively, of species $j . F_{j}$ is percentage frequency of occurrence of species $\mathrm{j}$ in total number of settings and $\mathrm{m}$ is total number of species. $\mathrm{IRI}_{\mathrm{j}}$ is the index of relative importance of species $\mathrm{j}$. IRI values were estimated for each species caught in gillnets set in inshore and offshore areas separately for the three reservoirs.

To investigate the underlying spatio-temporal pattern of the distribution and commonness of fish species, similarity of fish species occurrence in different sampling dates in the inshore and offshore areas was determined by Bray-Curtis similarity analysis (Bray and Curtis 1957). This analysis was performed for sorting based on group averages of $4^{\text {th }}$ root transformed \% IRI data for classification of sites/sampling dates based on the similarity matrix. Here, $4^{\text {th }}$ root transformation was performed in order to down-weight the importance of the common species so that the less dominant species play some role in determining similarity of samples (Clarke and Warwick 1994). Based on the same similarity matrix, sites/ sampling dates were ordinated by multidimensional scaling (MDS). These multivariate statistical analyses were performed using the PRIMER (Version 5.2.9) software (Clarke and Gorley 2001).

Attempts were then made to investigate whether these ordinations are related to water levels in the reservoirs.

\section{Results}

Fish composition expressed as mean catch per unit effort (CPUE in Nos $100 \mathrm{~m}^{-2}, \mathrm{hr}^{-1}$ ) is given in table 2 .

According to \%IRI (Table 3), the three most important species in the experimental gillnet catches of the mesh sizes $12.5 \mathrm{~mm}$ to $37 \mathrm{~mm}$ were A. melettinus, $P$. filamentosus and $P$. chola. In offshore areas of Minneriya, Rasbora daniconius also formed over 5\% of total IRI. None of the other species formed significant proportions in any of the reservoirs. Exotic cichlids were also negligible in the gillnet catches. The IRI for the gillnet 
Table 2. Fish composition expressed as mean catch per unit effort $\left(100 \mathrm{ind} \cdot \mathrm{m}^{-2}, \mathrm{hr}^{-1}\right)$ in three reservoirs based on experimental gillnet fishing (both small and large mesh gillnets) carried out from January 1999 to January 2001. Abbreviations for species names (Abb.) are used in figure 3 . The species marked with asterisks were caught only in large mesh (>52 mm) gillnets.

\begin{tabular}{|c|c|c|c|c|}
\hline Family/species & Abb. & Minneriya & Udawalawe & Victoria \\
\hline \multicolumn{5}{|l|}{ Cyprinidae } \\
\hline Amblypharyngodon melettinus (Val.) & Am & 88.961 & 37.325 & 38.570 \\
\hline Catla catla (Ham.-Buch.)* & Сc & & 0.013 & \\
\hline Chela laubuca (Ham.) & $\mathrm{Cl}$ & 0.396 & & \\
\hline Danio malabaricus (Jerdon) & $\mathrm{Dm}$ & 0.043 & 0.048 & 2.719 \\
\hline Esomus danrica (Val.) & Ed & 0.071 & & 0.384 \\
\hline Garra ceylonensis Bleeker & Gc & 0.120 & & \\
\hline Labeo dussumieri (Val.)* & Ld & 0.012 & 0.098 & \\
\hline L. rohita (Ham.) & $\mathrm{Lr}$ & & 0.060 & \\
\hline Puntius bimaculatus (Bleeker) & $\mathrm{Pb}$ & 0.107 & & \\
\hline P. chola (Ham.-Buch.) & Pc & 19.948 & 1.356 & 14.607 \\
\hline P. dorsalis (Jerdon) & Pd & 0.561 & 0.926 & 0.452 \\
\hline P. filamentosus (Val.) & $\mathrm{Pf}$ & 8.942 & 7.260 & 15.325 \\
\hline P. sarana (Ham.-Buch.) & Ps & 0.010 & & 0.003 \\
\hline P. vittatus Day & $\mathrm{Pv}$ & 1.300 & & \\
\hline Rasbora daniconius (Ham.-Buch.) & $\mathrm{Rd}$ & 8.067 & 2.240 & 0.061 \\
\hline Tor khudree (Sykes)* & Tk & & & 0.003 \\
\hline \multicolumn{5}{|l|}{ Bagridae } \\
\hline Mystus keletius (Val.) & $\mathrm{Mk}$ & 0.002 & 0.002 & \\
\hline M. vittatus (Bloch) & $\mathrm{Mv}$ & 1.665 & 0.084 & 0.515 \\
\hline \multicolumn{5}{|l|}{ Cichlidae } \\
\hline Etroplus maculatus (Bloch) & Em & 0.406 & & 0.018 \\
\hline E. suratensis (Bloch) & Es & 0.048 & 0.255 & 0.002 \\
\hline Oreochromis mossambicus (Peters) & Om & 0.252 & 0.037 & 0.381 \\
\hline O. niloticus (L.) & On & 0.359 & 0.085 & 0.074 \\
\hline Tilapia rendalli (Boulenger) & $\operatorname{Tr}$ & 1.407 & 0.004 & 0.023 \\
\hline \multicolumn{5}{|l|}{ Gobiidae } \\
\hline Glossogobius giuris (Ham.-Buch.) & $\mathrm{Gg}$ & 0.335 & 0.273 & 0.128 \\
\hline \multicolumn{5}{|l|}{ Hemirhamphidae } \\
\hline Hyporhamphus limbatus (Val.) & $\mathrm{Hl}$ & 0.947 & 0.625 & \\
\hline \multicolumn{5}{|l|}{ Anabantidae } \\
\hline Anabas testudineus (Bloch) & At & 0.088 & & \\
\hline \multicolumn{5}{|l|}{ Siluridae } \\
\hline Ompok bimaculatus (Bloch)* & $\mathrm{Ob}$ & 0.033 & 0.022 & \\
\hline \multicolumn{5}{|l|}{ Mastacembelidae } \\
\hline Mastacembelus armatus (Lacapede) & Ма & 0.052 & & 0.001 \\
\hline \multicolumn{5}{|l|}{ Ophicephalidae } \\
\hline Ophicephalus striatus (Bloch)* & Os & 0.002 & & \\
\hline \multicolumn{5}{|l|}{ Osphronemidae } \\
\hline Trichogaster pectoralis (Regan) & $\mathrm{Tp}$ & 0.014 & & \\
\hline \multicolumn{5}{|l|}{ Heteropneustidae } \\
\hline Heteropneustes fossilis (Bloch) & Hf & 0.208 & 0.014 & 0.045 \\
\hline Number of species & & 28 & 19 & 18 \\
\hline
\end{tabular}


Table 3. Percentage index of relative importance (\%IRI) of fish species caught in gillnets in inshore and offshore areas of the three reservoirs. The species which contributed more than $5 \%$ to the total IRI are indicated in bold numerals. $\mathrm{N}$ - Not caught.

\begin{tabular}{|c|c|c|c|c|c|c|}
\hline \multirow{3}{*}{ Species } & \multicolumn{6}{|c|}{ \% IRI } \\
\hline & \multicolumn{2}{|c|}{ Minneriya } & \multicolumn{2}{|c|}{ Udawalawe } & \multicolumn{2}{|c|}{ Victoria } \\
\hline & Inshore & Offshore & Inshore & Offshore & Inshore & Offshore \\
\hline A. melettinus & 38.0 & 26.5 & 52.7 & 66.6 & 47.5 & 31.0 \\
\hline A. testudineus & 0.0 & 0.0 & $\mathrm{~N}$ & $\mathrm{~N}$ & $\mathrm{~N}$ & $\mathrm{~N}$ \\
\hline C. laubuca & 0.0 & 0.0 & $\mathrm{~N}$ & $\mathrm{~N}$ & $\mathrm{~N}$ & $\mathrm{~N}$ \\
\hline D. malabaricus & 0.1 & $\mathrm{~N}$ & $\mathrm{~N}$ & $\mathrm{~N}$ & 0.4 & 2.1 \\
\hline E. danrica & 0.1 & 0.0 & $\mathrm{~N}$ & $\mathrm{~N}$ & 0.0 & 0.1 \\
\hline E. maculatus & 0.3 & 0.3 & $\mathrm{~N}$ & $\mathrm{~N}$ & $\mathrm{~N}$ & $\mathrm{~N}$ \\
\hline E. suratensis & 0.0 & 0.0 & 0.2 & 0.0 & $\mathrm{~N}$ & $\mathrm{~N}$ \\
\hline G. ceylonensis & 0.1 & 0.0 & $\mathrm{~N}$ & $\mathrm{~N}$ & $\mathrm{~N}$ & $\mathrm{~N}$ \\
\hline G. giuris & 0.0 & 0.2 & 0.4 & 0.1 & 0.0 & 0.1 \\
\hline H. fossilis & 0.3 & 0.1 & 0.0 & 0.0 & $\mathrm{~N}$ & 0.0 \\
\hline H. limbatus & 0.5 & 0.1 & 1.0 & 0.0 & $\mathrm{~N}$ & $\mathrm{~N}$ \\
\hline L. dussumieri & $\mathrm{N}$ & $\mathrm{N}$ & $\mathrm{N}$ & 0.1 & $\mathrm{~N}$ & $\mathrm{~N}$ \\
\hline L. rohita & $\mathrm{N}$ & $\mathrm{N}$ & 0.0 & 0.0 & $\mathrm{~N}$ & $\mathrm{~N}$ \\
\hline M. armatus & 0.0 & 0.1 & $\mathrm{~N}$ & $\mathrm{~N}$ & $\mathrm{~N}$ & $\mathrm{~N}$ \\
\hline M. kelatius & $\mathrm{N}$ & $\mathrm{N}$ & $\mathrm{N}$ & $\mathrm{N}$ & $\mathrm{N}$ & 0.0 \\
\hline M. vittatus & 2.0 & 0.4 & 0.0 & 0.0 & 0.2 & 0.1 \\
\hline O. mossambicus & 0.0 & 0.0 & 0.0 & $\mathrm{~N}$ & $\mathrm{~N}$ & $\mathrm{~N}$ \\
\hline O. niloticus & 0.0 & 0.0 & 0.0 & 0.0 & $\mathrm{~N}$ & $\mathrm{~N}$ \\
\hline P. bimaculatus & 0.0 & 0.0 & 0.0 & $\mathrm{~N}$ & $\mathrm{~N}$ & $\mathrm{~N}$ \\
\hline P. chola & 27.5 & 37.7 & 1.7 & 3.0 & 16.5 & 23.7 \\
\hline P. dorsalis & 0.4 & 0.1 & 1.7 & 1.7 & 0.2 & 0.4 \\
\hline P. filamentosus & 26.3 & 27.9 & 40.0 & 26.1 & 35.1 & 42.5 \\
\hline P. sarana & 0.0 & $\mathrm{~N}$ & 0.0 & $\mathrm{~N}$ & 0.0 & $\mathrm{~N}$ \\
\hline P. vittatus & 0.0 & $\mathrm{~N}$ & $\mathrm{~N}$ & $\mathrm{~N}$ & $\mathrm{~N}$ & $\mathrm{~N}$ \\
\hline R. daniconius & 4.1 & 6.5 & 2.4 & 2.4 & $\mathrm{~N}$ & 0.0 \\
\hline T. pectoralis & 0.0 & $\mathrm{~N}$ & 0.0 & $\mathrm{~N}$ & $\mathrm{~N}$ & $\mathrm{~N}$ \\
\hline T. rendalli & 0.0 & 0.0 & 0.0 & $\mathrm{~N}$ & $\mathrm{~N}$ & $\mathrm{~N}$ \\
\hline
\end{tabular}

catches indicate that A. melettinus, P. chola, P. filamentosus and R. daniconius were the four most dominant species in inshore and offshore areas of Minneriya and Udawalawe reservoirs whereas in Victoria reservoir, the four most dominant species were $A$. melettinus, P. filamentosus, $R$. daniconius and D. malabaricus (Fig. 2). However, the ranking of these dominant species showed differences between inshore and offshore areas as well as between reservoirs. For example, A. melettinus was the most dominant species in all three reservoirs except in offshore areas of Minneriya and Victoria reservoirs, where $P$. chola and $P$. filamentosus respectively registered the highest rank (Fig. 2). 

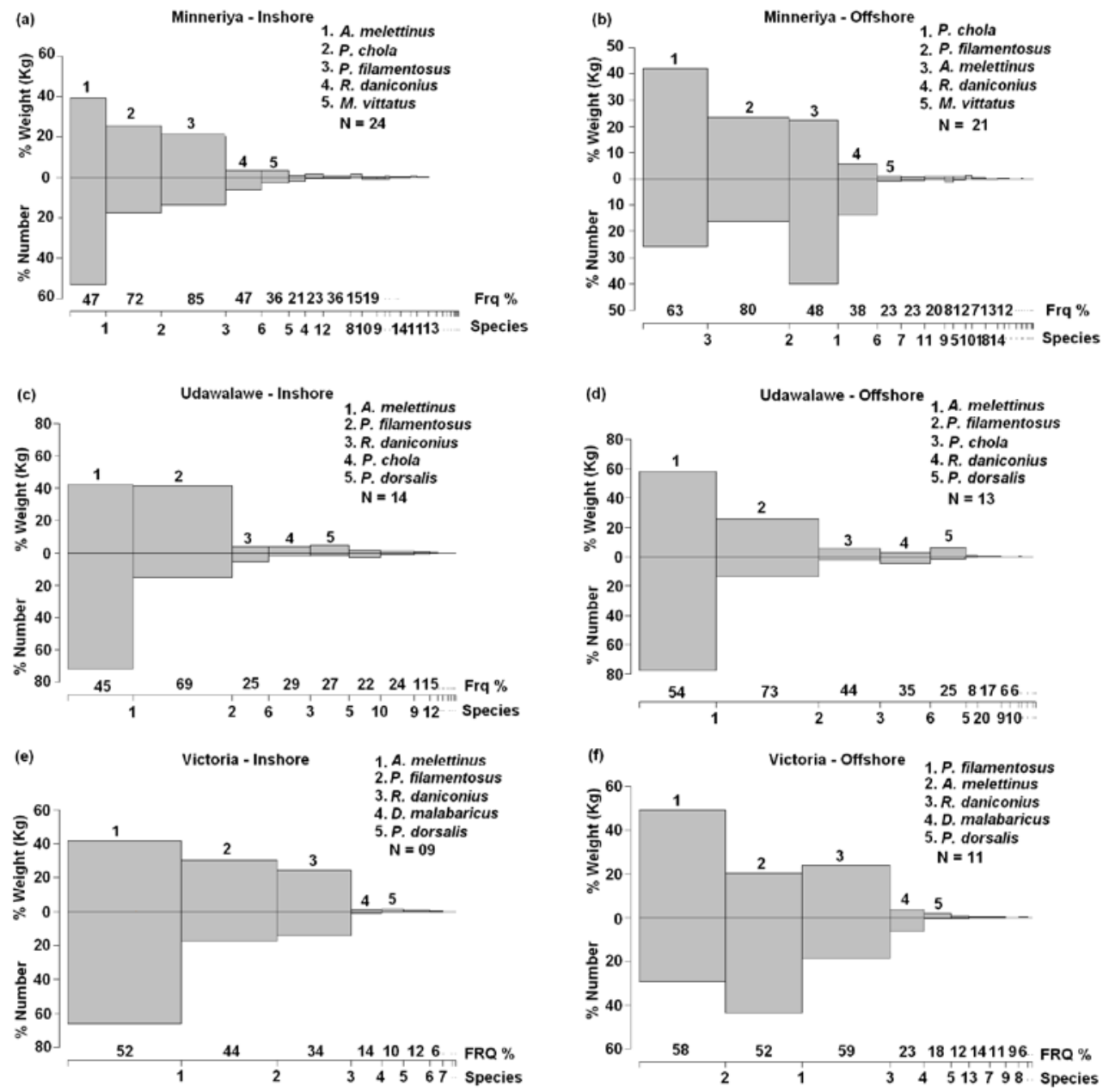

Figure 2. Relative importance of the fish species caught in gillnets of $12.5 \mathrm{~mm}$ to $37 \mathrm{~mm}$ mesh sizes. The five most dominant fish species in each reservoir are listed in each figure. (a) Minneriya; (b) Udawalawe; (c) Victoria; Weight (\%) - \% $\mathrm{CPUE}_{\mathrm{W}}$; Number (\%) - \% $\mathrm{CPUE}_{\mathrm{N}}$; \% FRQ - \% Frequency of occurrence; $\mathrm{N}$ - Number of species. For explanation of notations and terms, see the text.

Percentage IRI of different species during the sampling dates in inshore and offshore areas separately in the three reservoirs are shown in figure 3. They indicate that there is a spatio-temporal variation in the catchability of various species.

Bray-Curtis classification (Fig. 4) and MDS ordination (Fig. 5) indicated that the species composition in the gillnet catches in inshore and offshore areas during different sampling dates show spatial and temporal differences in all three reservoirs. The MDS ordination also indicates that 

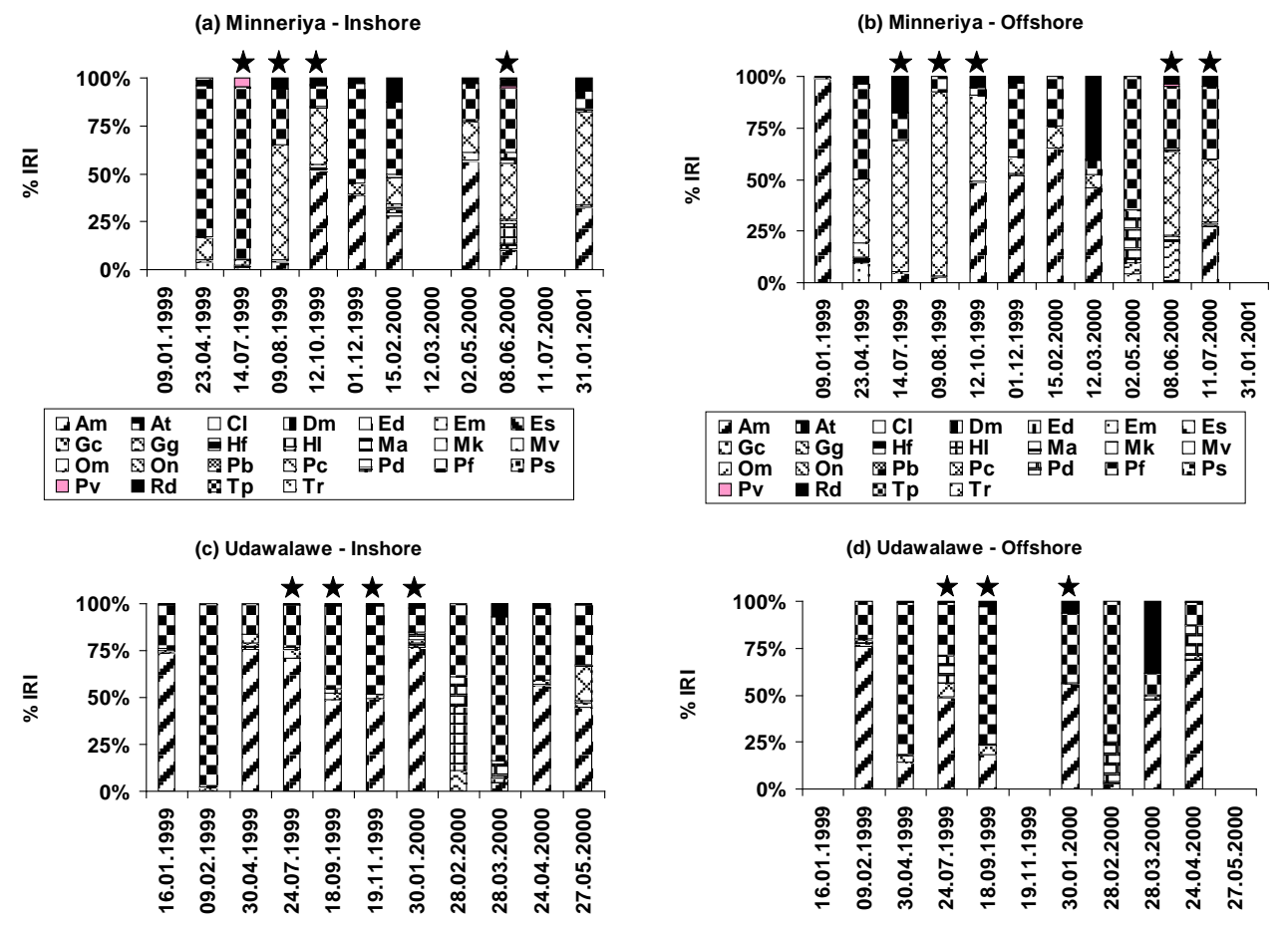

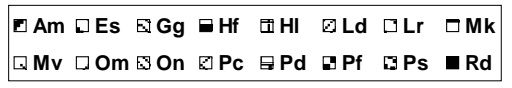

(e) Victoria - Inshore
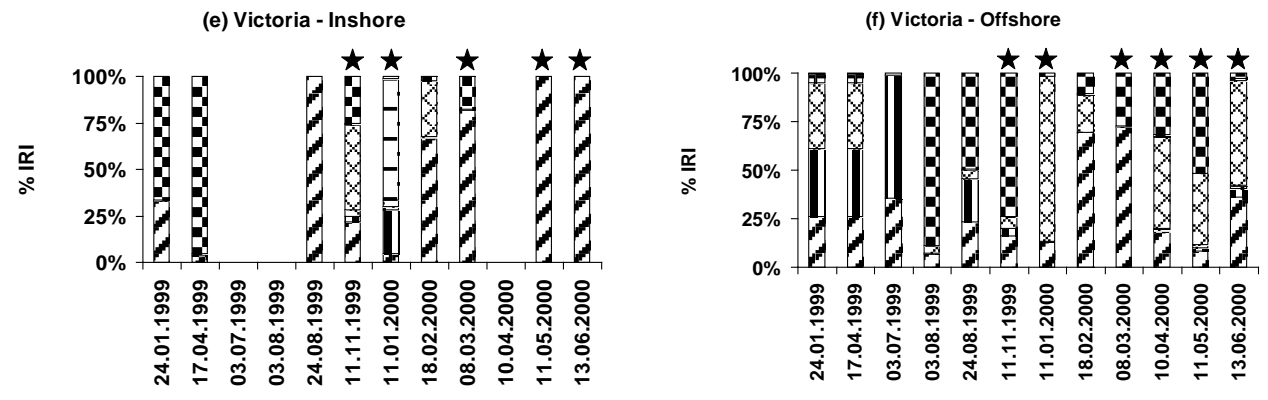

\begin{tabular}{|llllll|}
\hline$\square \mathrm{Am}$ & $\square \mathrm{Dm}$ & $\square \mathrm{Ed}$ & $\square \mathrm{Em}$ & $\square \mathrm{Gg}$ & $\square \mathrm{Mk}$ \\
$\square \mathrm{Mv}$ & $\mathrm{QPc}$ & $\mathrm{GPd}$ & $\square \mathrm{Pf}$ & $\square \mathrm{Rd}$ & \\
\hline
\end{tabular}

\begin{tabular}{|llllll|}
\hline$\square \mathrm{Am}$ & $\square \mathrm{Dm}$ & $\square \mathrm{Ed}$ & $\square \mathrm{Em}$ & $\square \mathrm{Gg}$ & $\boxminus \mathrm{Mk}$ \\
$\square \mathrm{Mv}$ & $\square \mathrm{Pc}$ & $\square \mathrm{Pd}$ & $\square \mathrm{Pf}$ & $\square \mathrm{Rd}$ & \\
\hline
\end{tabular}

Figure 3. Percentage IRI of different species during the sampling dates in inshore and offshore areas in the three reservoirs. Asterisks indicate the sampling dates during the seasons of low water level. Species abbreviations are as given in table 2.

species composition is somewhat similar in the months of low water level. Generally in a given sampling date, the species composition was similar between inshore and offshore areas. 


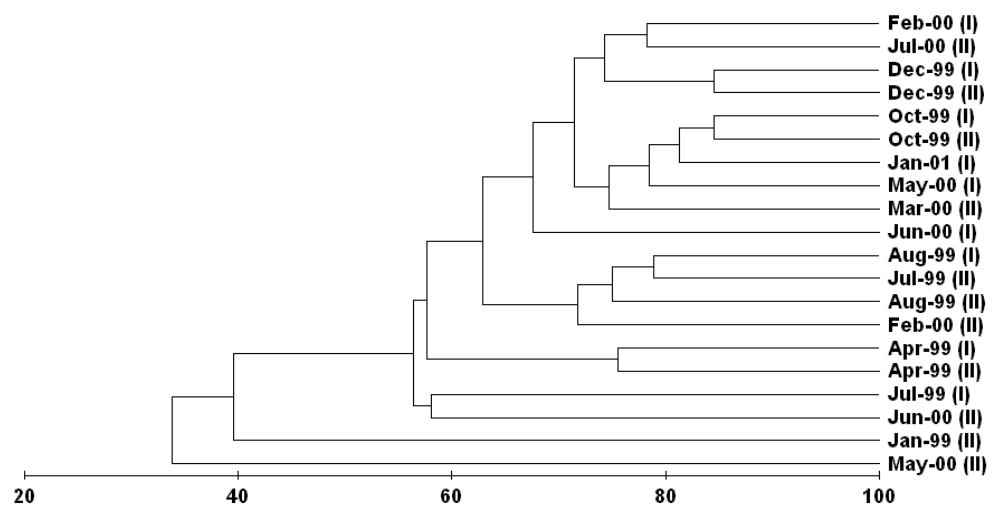

(a)

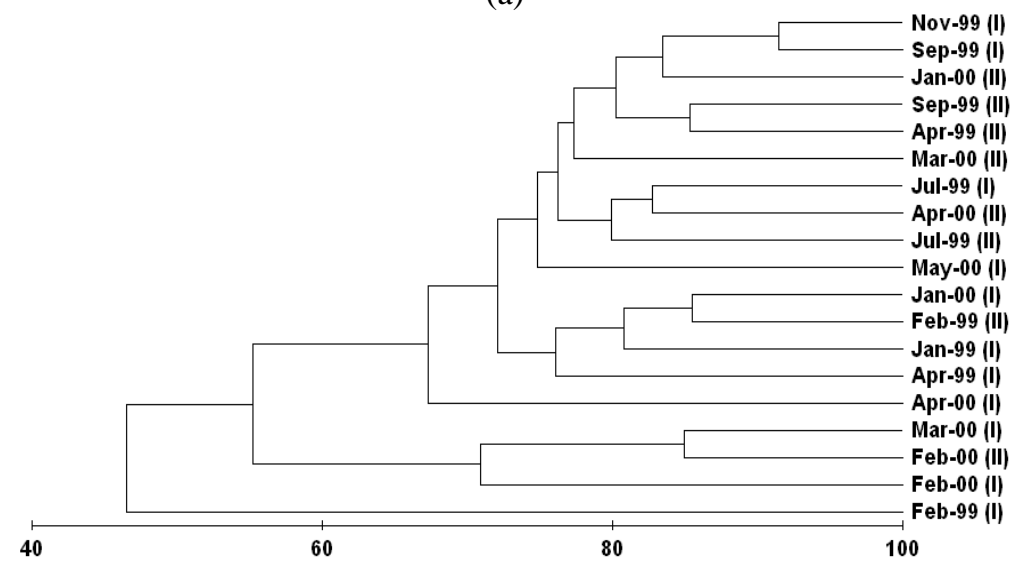

(b)

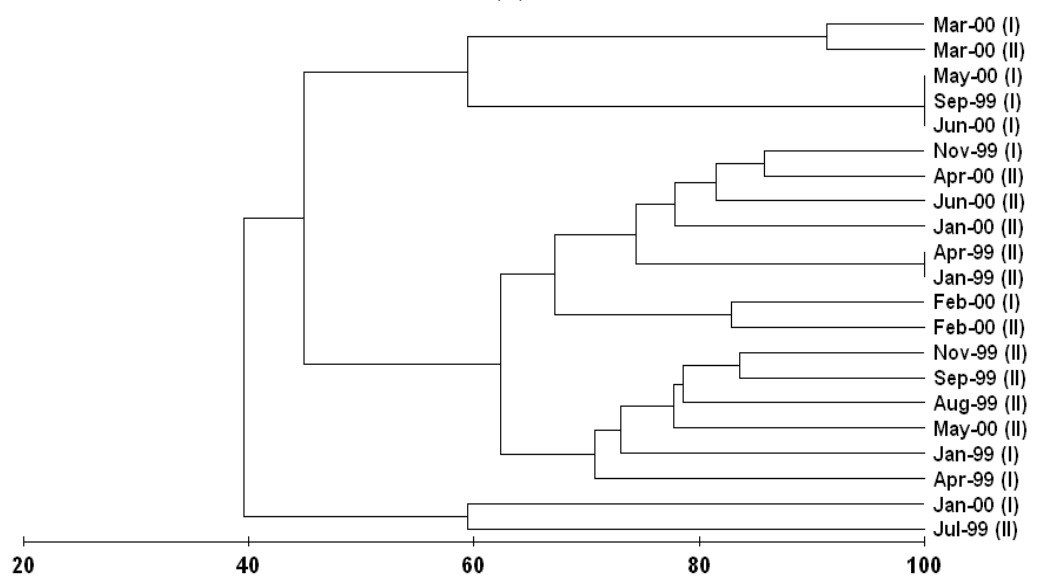

(c)

Figure 4. Bray-Curtis similarity of the species composition in the gillnet catches in inshore and offshore areas during different sampling dates in the three reservoirs. I - Inshore area; II - Offshore area. (a) Minneriya; (b) Udawalawe; (c) Victoria. 

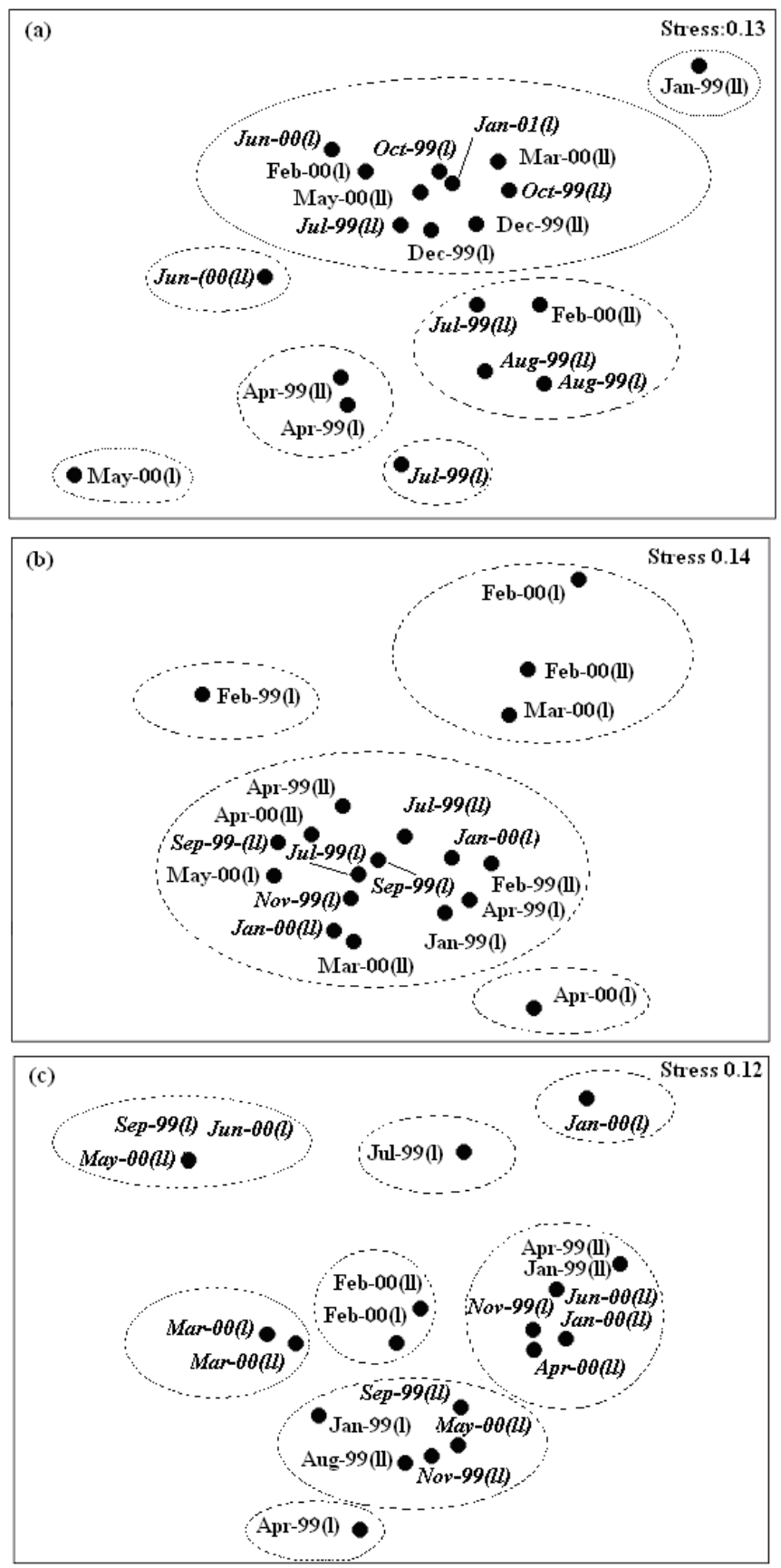

Figure 5. MDS ordination of species composition in the gillnet catches in inshore and offshore areas during different sampling dates in the three reservoirs. The sampling dates during the seasons of low water level are in italics. All stress values are $<0.14$ indicating sufficiency of two-dimensional ordination of datasets. I - Inshore area; II - Offshore area. (a) Minneriya; (b) Udawalawe; (c) Victoria. 


\section{Discussion}

The species that occur in reservoirs are essentially those which have drawn from associated riverine habitats. Reservoirs are known to be of intermediate characteristics between rivers and lakes because they consist of a riverine zone close to inflows, lacustrine zones close to the bund and intermediate zones between these two extremes (Thornton et al. 1990). As such, it can be expected that the reservoirs can harbour many fish species ranging from those adapted to riverine habitats to those adapted to lacusrine habitats. As tropical reservoirs in most parts of Asia do not have species adapted to lacustrine habitats, those which can colonize limnetic zones of reservoirs are indigenous fish species which prefer consuming continuously available food resources as is the case in slow flowing habitats in rivers. Yap (1999) also mentioned that colonization success of riverine species in newly impounded reservoirs depends on the habitat utilization of fish species drawn from riverine habitats. This suggests that the fish species which can colonize various habitats in reservoirs where there are no indigenous lacustrine species are not essentially the exotics with pre-adaptation to lacustrine conditions but those which prefer limnetic habitats.

According to Fernando and Holčik (1991) riverine species are not successful colonizers of reservoirs. They have argued that successful colonization of reservoirs is possible for lacustrine or lacustrine-adapted species. However, reservoirs being intermediate between rivers and lakes, can also be colonized by limnophilic species drawn from associated riverine habitats (Yap 1999). The availability of their preferred food in reservoirs also facilitates their colonization success in reservoirs. Hofer and Schiemer (1983) and Weliange and Amarasinghe (2003a; 2003b; 2007) have shown that minor cyprinid species such as $A$. melettinus, $P$. chola and $P$. filamentosus feed mainly on phytoplankton which is the most abundant food category in reservoirs.

The main objective of this study was to provide data to support the development of applicable guidelines for exploitation of untapped fishery resources in Sri Lankan reservoirs. Previous studies (Amarasinghe 1985; 1990; De Silva and Sirisena 1987; 1989; Sirisena and De Silva 1988; Pet et al. 1996) have shown that small cyprinids in Sri Lankan reservoirs could be differentially harvested using small mesh $(<52 \mathrm{~mm}$ stretched mesh) gillnets. It is a fact however, that introduction of a subsidiary fishery for these untapped fishery resources has to be done with sufficient manage- 
ment measures, especially due to the reason that fishers in Sri Lankan reservoirs are known to increase efficiencies of their fishing methods (Amarasinghe and Pitcher 1986; Amarasinghe and De Silva 1992) and to use illegal fishing methods such as shore seine nets (Fernando 1967; De Silva 1985; Amarasinghe and De Silva 1992). As such, it is imperative to define clear guidelines to introduce a subsidiary fishery to exploit these untapped fishery resources, which can co-exist with the present gillnet fishery targeting mainly exotic cichlids.

The present analysis indicates that the \%IRI of exotic cichlids which were caught in gillnets both in inshore and offshore areas were very insignificant. It must be noted that the shallowest depth where gillnets of the panel height of $1.5 \mathrm{~m}$ can be operated is exactly the same as gillnet height. The cichlid species are known to exhibit depth preferences according to body size, i.e., smaller individuals prefer shallow, littoral areas whereas adults prefer deeper, pelagic zones (Caulton and Hill 1973; Caulton 1975; Ribbink and Hill 1979). It is therefore unlikely that juveniles of exotic cichlids are caught in small mesh $(<37 \mathrm{~mm})$ gillnet which are set in the areas with depths greater than 1.5.m as has been evident from the present investigation.

In general, species composition in gillnets catches in inshore and offshore areas shows seasonal differences possible due to the changes in catchability of various species in gillnets. In inshore areas of all three reservoirs, A. melettinus was the most important species. The relative importance of $P$. filamentosus in inshore areas of Udawalawe reservoir was also high. However, in offshore areas of Udawalawe reservoir, P. chola showed the highest dominance whereas $P$. filamentosus was the most dominant in offshore areas of Victoria reservoir. The species composition expressed as \% IRI appears to be influenced by water level fluctuations in reservoirs perhaps due to inshore-offshore migration of individual fish species associated with the water level fluctuations. Despite the sitespecific differences in species distribution and abundance and their temporal variations, a small mesh (12.5 $\mathrm{mm}$ to $37 \mathrm{~mm})$ gillnet fishery with the minimum panel height of $1.5 \mathrm{~m}$ can be introduced to exploit minor cyprinids in Sri Lankan reservoirs. However, temporal and spatial variation in the catchability of small-sized indigenous cyprinid species might be a crucial factor to be considered when introducing subsidiary fishery for them due to the reason that seasonal variations in catch efficiencies would obviously affect income of fishers. Also as suggested by De Silva and Sirisena (1989), once such a fishery is introduced the exploitation levels should be closely monitored to determine the optimal fishing strategies. 
In most tropical reservoirs, small-sized fish species are known to be abundant (Ahmed et al. 2001; Jutagate et al. 2003; Roos et al. 2007), and therefore the present finding are of significance in regional context. As small-sized cyprinids are rich with micronutrients, especially Vitamin A (Roos et al. 2007), introduction of a subsidiary fishery to exploit this untapped resource is further justifiable as regards to human health. Also this will help increasing reservoir fisheries production through more complete exploitation of fish communities in Sri Lankan reservoirs as suggested by Pet et al. (1996). Exploitation of small cyprinids is no way considered as shifting the fishery towards lower trophic levels as shown by Pauly et al. (1998; 2002) in most fisheries because small cyprinids and exotic cichlids which dominate the reservoir fisheries production in Sri Lanka share more or less similar trophic levels in reservoir fish communities.

\section{Acknowledgements}

This study was carried out as part of a research project funded by European Union INCO-DC Programme Project Number: IC18-CT-0190. We are thankful to Mr. M.G. Ariyaratne for his assistance in experimental fishing.

\section{References}

Ahmed, K.K.U., J.B. Hambrey and Z. Rahaman. 2001. Trends in interannual yield variation of reservoir fisheries in Bangladesh, with special reference to Indian major carps. Lakes and Reservoirs: Research and Management 6:85-94.

Amarasinghe, U.S. 1985. Studies on the exploitation of minor cyprinids in Parakrama Samudra, a man-made lake in Sri Lanka, using gillnets. Journal of the National Aquatic Resources Agency (Sri Lanka) 32:11 -23.

Amarasinghe, U.S. 1990. Minor cyprinid resources in a man-made lake in Sri Lanka: a potential supplementary source of income for fishermen. Fisheries Research 9:8189.

Amarasinghe, U.S. 1998. Reservoir fisheries management in Sri Lanka: Achievements, mistakes and lessons for future. International Review of Hydrobiology 83 (Special Issue):523-530.

Amarasinghe, U.S. and S.S. De Silva. 1992. Empirical approaches for evaluating the efficiencies of different fishing methods in tropical, shallow reservoirs: a Sri Lankan case study. In: Reservoir Fisheries of Asia (ed. S.S. De Silva), pp. 217-227. International Development Research Centre, Ottawa. 
Amarasinghe, U.S. and T.J. Pitcher. 1986. Assessment of fishing effort in Parakrama Samudra, an ancient man-made lake in Sri Lanka. Fisheries Research 4:271-282.

Amarasinghe, U.S., P.A.D. Ajith Kumara and M.H.S. Ariyaratne. 2002. Role of nonexploited fishery resources in Sri Lankan reservoirs as a source of food for cage aquaculture. In: Management and Ecology of Lake and Reservoir Fisheries (ed. I.G. Cowx), pp. 332-343. Fishing News Books, Blackwell Science Ltd., Oxford.

Bray, J.R. and J.T. Curtis. 1957. An ordination of the upland forest communities of southern Wisconsin. Ecological Monographs 27:325-349.

Caulton, M.S. and B.J. Hill. 1973. The ability of Tilapia mossambica (Peters) to enter deep water. Journal of Fish Biology 5:783-788.

Caulton, M.S. 1975. The ability of the cichlid fishes Tilapia rendalli Boulenger, Tilapia sparrmanii A. Smith and Hemihaplochromis (= Pseudocreni1abrus) philander (M. Weber) to enter deep water. Journal of Fish Biology 7:513-517.

Clarke, K.R. and R.N. Gorley. 2001. PRIMER v5: User manual/Tutorial. PRIMER-E Ltd, Plymouth. 91 pp.

Clarke, K.R. and R.M. Warwick. 1994. Change in marine communities: an approach to statistical analysis and interpretation. Plymouth Marine Laboratory, Plymouth. 144 pp.

De Silva, S.S. 1985. Status of the introduced cichlid Sarotherodon mossambicus (Peters) in the reservoir fishery of Sri Lanka: a management strategy and ecological implications. Aquaculture and Fisheries Management 16:91-102.

De Silva, S.S. 1988. Reservoirs of Sri Lanka and their fisheries. FAO Fisheries Technical Paper 298. 128 pp.

De Silva, S.S. and H.K.G. Sirisena. 1987. New fish resources of reservoirs in Sri Lanka. Feasibility of introduction of a subsidiary gillnet fishery for minor cyprinids. Fisheries Research 6:17-34.

De Silva S.S. and H.K.G. Sirisena. 1989. New fish resources of reservoirs in Sri Lanka: 3. Results of commercial-scale trials and yield estimates of a gillnet fishery for minor cyprinids. Fisheries Research 7:279-287.

Fernando, C.H. 1967. The beach seine fishery in Ceylon's freshwaters. Indo-Pacific Fisheries Commission Current Affairs Bulletin 50:1-21.

Fernando, C.H. 1984. Reservoirs and lakes in South-East Asia (Oriental Region). In: Lake and Reservoir Ecosystems (ed. F.B. Taub), pp. 411-446. Elsevier, Amsterdam.

Fernando, C.H. and J. Holčik. 1991. Fish in reservoirs. Internationale Revue der gestamten Hydrobiologie und Hydrographie 76:149-167.

Hofer R. and F. Schiemer. 1983. Feeding, assimilation and energy conversion in two species of herbivorous fish. In: Limnology of Parakrama Samudra, Sri Lanka: a case study of an ancient man-made lake in the tropics (ed. F. Schiemer), pp. 155165. Developments in Hydrobiology 12, Dr. W. Junk Publishers, The Hague.

Hofer, R., W. Salvenmoser and F. Schiemer. 2003. Regulation of diurnal filter feeding by a novel gill structure in Amblypharyngodon melettinus (Teleostei, Cyprinidae). Zoomorphology 122(3):113-118.

Jutagate T., S.S. De Silva and N.S. Mattson. 2003. Yield, growth and mortality rate of the Thai river sprat, Clupeichthys aesarnensis, in Sirinthorn reservoir, Thailand. Fisheries Management and Ecology 10:221-231.

Kolding, J. and A. Skaalevik. 2007. Pasgear II, Version 2.3. University of Bergen, Department of Biology, Thormoehlensgt., Bergen, Norway. URL: www.cdcf.no/data/pasgear.

Oglesby, R.T. 1985. Management of lacustrine fisheries in the tropics. Fisheries 10:16-19. 
Pauly, D., V.Christensen, J. Dalsgaard, R. Froese and F. Torres Jr. 1998. Fishing down marine food webs. Science 279:860-863.

Pauly, D., V. Christensen, S. Guénette, T.J. Pitcher, U.R. Sumaila, C.J. Walters, R. Watson and D. Zeller. 2002. Towards sustainability in world fisheries. Nature 418:689-695.

Pet, J.S. and G.J. Piet, 1993. The consequences of habitat occupation and habitat overlap of the introduced tilapia Oreochromis mossambicus and indigenous fish species for fishery management in a Sri Lankan reservoir. Journal of Fish Biology 43 (Supplement A):193-208.

Pet, J.S., G.J.M. Gevers, W.L.T. van Densen and J. Vijverberg. 1996. Management options for a more complete utilization of the biological fish production in Sri Lankan reservoirs. Ecology of Freshwater Fish 5:1-14.

Pethiyagoda, R. 1991. Freshwater Fishes of Sri Lanka. Wildlife Heritage Trust of Sri Lanka, Colombo. $362 \mathrm{pp}$.

Piet, G.J. \& J. Vijverberg 1998. An ecosystem perspective for the management of a tropical reservoir fishery. International Review of Hydrobiology 83 (Special Issue): 103-112.

Ribbink, A.J. and B.J. Hill 1979. Depth equilibration by two predatory cichlid fish from Lake Malawi. Journal of Fish Biology 14:507-510.

Roos, N., Md. A. Wahab, M.A.R. Hossain and S.H. Thilsted (2007) Linking human nutrition and fisheries: Incorporating micronutrient-dense, small indigenous fish species in carp polyculture production in Bangladesh. Food and Nutrition Bulletin 28(2)(supplement): S280-S293.

Schiemer, F. \& R. Hofer, 1983. A contribution to the ecology of the fish fauna of the Parakrama Samudra Reservoir. In: Limnology of Parakrama Samudra, Sri Lanka: a case study of an ancient man-made lake in the tropics (ed. F. Schiemer), pp. 135-164. Developments in Hydrobiology 12, Dr. W. Junk Publishers, The Hague.

Silva, E.I.L. and G.A.R.K. Gamlath. 2000. Catchment characteristics and water quality of three reservoirs (Victoria, Minneriya and Udawalawe) in Sri Lanka. Sri Lanka Journal of Aquatic Sciences 5:55-73.

Silva, E.I.L., D. Simon and F. Schiemer. 2008. Catchment characteristics, hydrology, limnology and socio-economic features of three reservoirs in Sri Lanka. In: Aquatic Ecosystem and Development: Comparative Asian Perspectives (eds. F. Schiemer, D. Simon, U.S. Amarasinghe and J. Moreau), pp. 19-44. Biology of Inland Waters, Backhuys Publishers, Leiden.

Sirisena H.K.G. and S.S. De Silva 1988. New fish resources of reservoirs in Sri Lanka II: Further studies on a gillnet fishery for minor cyprinids. Fisheries Research 7:1729.

Sricharoendham B., U.S. Amarasinghe, R.P.P.K. Jayasinghe and S.M. Aypa 2008. Status of the capture fisheries in four Asian reservoirs and a volcanic lake. In: Aquatic Ecosystem and Development: Comparative Asian Perspectives (eds. F. Schiemer, D. Simon, U.S. Amarasinghe and J. Moreau), pp. 265-284. Biology of Inland Waters, Backhuys Publishers, Leiden.

Thornton, K.W., B.L. Kimmel and F.E. Payne (eds). 1990. Reservoir Limnology: Ecological Perspectives. A Wiley Interscience Publication, John Wiley and Sons, New York. 348 pp. 
Weliange W.S. and U.S. Amarasinghe. 2003a. Accounting for diel feeding periodicity in quantifying food resource partitioning in fish assemblages in three reservoirs of Sri Lanka. Asian Fisheries Science 16:203-213.

Weliange W.S. and U.S. Amarasinghe. 2003b. Seasonality in dietary shifts in sizestructured freshwater fish assemblages in three reservoirs of Sri Lanka. Environmental Biology of Fishes 68(3):269-282.

Weliange, W.S. and U.S. Amarasinghe. 2007. Relationship between body shape and food habits of fish from three reservoirs of Sri Lanka. Asian Fisheries Science 20: 257-270.

Yap, S.Y. 1999. Riverine and lacustrine fish communities in Southeast Asia. In: Fish and fisheries of lakes and reservoirs in Southeast Asia and Africa (eds W.L.T. van Densen and M.J. Morris), pp. 13-27. Westbury Publishing, Otley. 